Vol. 13 , No. 1

ISSN: 2085 - 4609 (Print), e- ISSN 2656-0208

Journal homepage: bit.ly/UltimaComm

\title{
Identification of Relationship Maintenance in Chinese Muslim Marriages in Film “Bidadari Mencari Sayap"
}

\section{Silvia Pristianita \& Rustono Farady Marta}

To cite this article:

Pristianita, S., \& Marta, R.F. (2021). Identification of Relationship Maintenance in Chinese Muslim Marriages in Film "Bidadari Mencari Sayap", Ultimacomm, 13(1), 169-186.

https://doi.org/https://doi.org/10.31937/ultimacomm.v13i1.2035

Ultimacomm publishes research articles and conceptual paper in the field of communication, mainly digital journalism and strategic communication. It is published twice a year by the Faculty of Communication of Universitas Multimedia Nusantara

Submit your article to this journal $\square$ 


\title{
Identification of Relationship Maintenance in Chinese Muslim Marriages in Film "Bidadari Mencari Sayap"
}

\author{
Silvia Pristianita \& Rustono Farady Marta \\ Magister Ilmu Komunikasi, Universitas Bunda Mulia \\ Email: silvia.pristianita98@gmail.com, rmarta@bundamulia.ac.id
}

Received May 11, 2021; Revised Jun. 26,2021; Accepted Jun 30, 2021

\begin{abstract}
Culture and reality in society are often described in various ways, one of which is through literary works such as films. The film is one of the media that is often used to convey the implied meaning and message. "Bidadari Mencari Sayap" is one of the films shown on the side streams of the Disney+ platform. "Bidadari Mencari Sayap," which officially aired on 2 October 2020, portray a very complex wedding story. This film tells the story of a household between a Muslim husband and wife and a Chinese convert. This study will analyse the film using qualitative methods and interpretative paradigms. In addition, the author will use relational maintenance from Laura Stanford and Canary, which consists of ten elements in maintaining relationships, namely positivity, openness, assurance, sharing tasks, social networks, join activities, mediated communication, avoidance, antisocial and humour. The explanation is elaborated with a grand syntagmatic from Christian Metz Semiotics, namely autonomous shot, the parallel syntagm, the bracketing syntagm, the descriptive syntagm, the alternating syntagm, the scene, and the scene episodic sequence, and the ordinary sequence. The research results show that the film "Bidadari Mencari Sayap" applies eight of the ten elements of relational maintenance theories that produce four syntagms and three autonomous shots with various types, namely subjective insert, explanatory insert also displaced diegetic. The differences between the two characters do not become a barrier, and each partner has their respective duties to maintain the relationship that has been built together.
\end{abstract}

Keywords: Christian Metz Semiotics; Relational Maintenance Theory; Film; "Bidadari Mencari Sayap"

\section{INTRODUCTION}

Indonesia is a multicultural country and consists of various ethnicities, tribes, and cultures with various values. Culture and realities that exist in society are often depicted in various forms of literary works, one of which is film. Movies are part of pop cultures, just like music, books, and others (Suryanto, 2016). According to Fanananie (2001), literary works can be understood through three perspectives. The first perspective categorises literary works as a form of social document that represents the situation when the literary work was created. In other words, a literary work describes the time when the work was created. The second perspective is that a literary work is a reflection of the social 
conditions of the author of the work. In other words, literary works are a personal reflection of the author and his views on the social reality that occurs. The third perspective is that a literary work is a manifestation of social reality that does occur in society. Literary work can be said to be an embodiment of fiction made by the author who presents various realities and facts in life but is added to the story of the author's imagination (Sitompul and Simaremar, 2017).

Various events and stories from the past to cultural issues are often the inspiration for making a film story. Various points of view and values that are believed by some members of society can be represented by the film. Many elements are merged into one in a film so that the audience is actually required to be more critical to be able to understand the ideology and moral messages to the representation of everyday life implied in the films they watch (Oktavianus, 2018). This is, of course, in line with the function of the film, which is informative, social, educative, and persuasive. Films are felt to have a significant impact on people's lives because they are produced based on cultural products, which of course, have various meanings (Lilis et al., 2017). If studied with semiotics, the film is a text contained at the level of markers. The film consists of a series of images and images that describe activities that actually occur in reality (Ali, 2019).

"Bidadari Mencari Sayap" is a film made by PT MD Pictures Tbk. in collaboration with Citra Cinema. The film, which premiered on Disney+ Hotstar on 2 October 2020, depicts the complexity of the story of households of different ethnicities and the process of religious adjustment. The film "Bidadari Mencari Sayap" is a drama genre. Many drama genres are produced. After all, drama can reach a wider audience because it is considered relevant to their daily lives. Films with a drama genre tend to have a related theme, story, character, and atmosphere with the society (Sidabutar, 2019). The title of the film "Bidadari Mencari Sayap" turns out to have its own story. Aria Kusumadewa as the director of this film, said that the title was given as a gift by one of the directors who succeeded in leading Indonesia to become an Oscar nomination for the Best International Feature Film category in 2020, namely Garin Nugroho (Diananto, 2020).

Aria Kusumadewa tells the story of a married couple who have different cultural backgrounds in this film. Complexity occurs in Reza's married life as a husband who is of Arab descent who is married to Angela, a woman of Chinese descent who chooses to convert to Islam to marry Reza. The differences that exist make various conflicts actually occur in their domestic life (Sari, 2020). In general, marriage in Indonesia is the inner and outer bond of a man and a woman. Marriage is a commitment that is built together between the prospective husband and wife. In Indonesia, marriages often occur between ethnic groups, religions, and even religions because Indonesia has a multicultural society of various races, ethnicities, and religions (Abadi et al., 2017).

Adjusting from the old religion to the new religion can sometimes cause problems after a religious conversion. This is because changes to self-identity are undoubtedly difficult to do, especially if the old identity has become a habit during the previous lifetime. 
Problems not only come from the internal side, such as family, but can also come from the external side such as the wider community's response regarding the decisions taken (Abdilah and Sjafe'i, 2019). In reality, being a Chinese Muslim is not an easy decision because they are considered a minority within a minority or a double minority. So, the rejection does not only occur from the family, but the presence of Chinese Muslims is also not necessarily acceptable for the Muslim community (Zuhri and Wahyudi, 2019). In life, conflict can be characterised by disagreements or differences. Conflict can create tension or other difficulties between two or more parties (Pertiwi et al., 2020). In fact, in 2020, in Indonesia, 176,683 couples divorced due to ongoing disputes and quarrels (BPS, 2021)(BPS, 2021)(BPS, 2021).

The main focus in this article is to dissect the description of relationship maintenance theory from Laura Stanford and Canary, which focuses on how to keep relationships in the desired state. Laura and Canary divide their theory into ten elements (Nurhasanah and Naryono, 2017). The film "Bidadari Mencari Sayap," which presents the story of a married couple with different cultural backgrounds, converts to Islam and Muslim, becomes an interesting blend in providing an implied meaning about the pattern of maintaining relationships in the context of differences and conflicts that arise in it. In addition to using relationship maintenance theory, this study also uses Christian Metz's semiotics with eight syntagmas, namely the autonomous shot, the parallel syntagm, the bracketing syntagm, the descriptive syntagm, the alternating syntagm, the scene, the episodic sequence, and the ordinary sequence. The large syntagmatic category from Christian Metz's semiotics is used to describe the meaning contained in the film "Bidadari Mencari Sayap."

In married life, conflict is a common condition. In one study conducted by Gurin, conflict can occur in married life. As many as $45 \%$ of married people agree that in life together there will be various problems. Meanwhile, $32 \%$ of married couples said that they were very happy and had never experienced disagreements (B et al., 2018). Conflict in a relationship can occur due to various factors, both internally and externally. Internal factors that can influence the occurrence of conflict are physical, personality, and economic, social, and cultural differences in status, especially when there is a conflict and the difference is unacceptable to the parties involved. External factors are conflicts that occur because there are third parties or other external parties in a relationship (Prameswari, 2017).

Canary explains that relational maintenance is done to protect a relationship so that it is maintained and stable (Canary \& Yum, 2015). The relational maintenance theory proposed by Laura Stanford and Canary has ten elements to maintain and also maintain a relationship (Nurhasanah \& Naryono, 2017). The ten elements consist of positivity, openness, assurance, sharing tasks, social networks, join activities, mediated communication, avoidance, antisocial and humour. 
Positivity is a positive attitude in a person to make a partner feel happy, such as giving praise and giving freedom to partners to be themselves. Partners must play a pleasant person and encourage their partner as one of their closest people. Openness is a time when couples can discuss, open up, and listen to each other, allowing an exchange of ideas. Openness is also known as deep talk, which is honest talk from the bottom of the heart.

Assurance is the attitude of a partner that provides certainty and assurance regarding a commitment to foster trust in the partner. Sharing tasks are actions that are carried out by couples together. Sharing tasks can also be interpreted as a couple knowing their respective roles and running them well, for example, doing work together and dividing tasks.

The social network is a couple's attitude to get closer and spend time communicating with people around their partner. In fact, in maintaining relationships with our partners, we must also establish relationships with people who are around our partners, such as family or friends.

Joint activities are couples who spend time together, such as eating together, chatting, etc. Mediated communication is communication with a partner that is done through media, such as telephone, letter, video call and others. Avoidance is an act of avoiding things that are not liked by your partner and allow it to trigger a conflict.

Antisocial is an attitude that shows unfriendliness towards a partner or even the use of violence. This attitude must, of course, be avoided in resolving a problem or conflict. Humour is the attitude of a partner to lighten the mood to make the relationship more enjoyable.

Semiotics is basically a sign science that is used to analyse the signs that are around us. Signs in semiotics are not signs in the literal sense, but more broadly, such as the structure of literary works, films, buildings, and other signs in society (Tianotak \& Asy'ari, 2019). One of the philosophers who came from France, Christian Metz, is the creator of film semiotics. The meaning of film semiotics described by Metz is conveyed through the denotative elements contained in the film. Metz argues that film semiotics means that films combine images and sounds that form a semantic continuity (Kusuma Dewi et al., 2017).

Language is all forms of communication. In this case, cinema can be interpreted as a language system. This statement is in accordance with Metz's (1991) statement, namely "it is not because the cinema is a language that it can tell us such fine stories, but rather it has become a language because it has been told such fine stories" (Marta and Robin, 
2019). Metz popularised the large syntagmatic category, which consists of eight syntagms, namely the autonomous shot, the parallel syntagm, the bracketing syntagm, the descriptive syntagm, the alternating syntagm, the scene, the episodic sequence, and the ordinary sequence (Erviannisa and Christantyawati, 2017).

The autonomous shot is a syntagm consisting of one shot. The shot can be a single shot sequence. There are four types of inserts. The first insert is a non-diegetic insert or the insertion of an insert that has absolutely no space and time continuity in the film. The second insert is the subjective insert, which is a shot that depicts a personal point of view such as past memories, imagining things, dreaming, or hallucinating. The third insert is displaced diegetic, which is the insertion of a shot in space and time, where the shot is outside the scene. The third insert is an explanatory insert which is an insert that aims to explain events to the audience.

Parallel syntagma is a syntagma that consists of combining shots and images that have contrasting differences in a scene. Syntagm brackets combine images that share a common theme and represent examples of an order of reality. Descriptive syntagma is a syntagma that has continuity in space and time and describes a series of events. Alternating syntagma is a syntagma that has more than one shot and also describes two different scenes that occur alternately and have space and time relationships.

The scene is a collection of shots that chronologically displays a particular scene about an event, its action and its depiction as if not paused. The episodic sequence is a linear syntagm but does not occur continuously and consists of more than one shot. This syntagm tends to talk about one thing and also the same goal. Ordinary sequences consist of more than one shot that is chronological in nature which emphasises the critical points of an ongoing scene (Ali, 2019).

\section{METHODS}

In this study, the researcher used a qualitative approach, namely the process of scientific investigation aimed at obtaining a holistic understanding of the existing problems (Mujahidah \& Jaunedi, 2021). Paradigm is a fundamental way of perceiving thought. In cross-cultural communication, there are three main paradigms, namely the functional paradigm, the interpretive paradigm, and also the critical paradigm (Fernando et al., 2020). Qualitative research has several characteristics. The first key instrument of research is the person conducting the research. Qualitative research must be able to describe an object or phenomenon in the form of a narrative. In addition, qualitative research focuses on the process as well as the results of the research. Then, research data analysis was carried out inductively and in-depth exploration (Ghony \& Almanshur, 2010). The paradigm used in this study is the interpretive paradigm. That is, this study did not 
test hypotheses or make predictions. Research that has a descriptive nature describes an event or situation that is currently happening. The interpretive paradigm basically understands the behaviour of humans or creates an understanding and interpretation of something (Isnaini \& Arzak, 2019).

The object of analysis in this research was a text in the form of a film entitled "Bidadari Mencari Sayap," which is analysed using the semiotic tradition. Semiotics is a branch of science that focuses on studying signs. Signs are expected to convey messages, both verbally and non-verbally (Indriani and Rosfiantika, 2018). The author divided the film, which has a duration of 89 minutes, into sequences, scenes and shots. Sequence, scene and shot will then be selected as the unit of analysis of the study based on the criteria that best suit the aims and objectives of this study, namely finding the values of maintaining relationships in Chinese Muslim marriages and describing the large syntagmatic category of Christian Metz.

\section{RESULTS AND DISCUSSIONS}

Based on observations of the film "Bidadari Mencari Sayap," several ways of maintaining relationships were found in the relationship between Muslim husband and wife and Chinese converts who were often shown after the conflict. Based on the ten elements in relational maintenance theory, the film "Bidadari Mencari Sayap" broadly uses eight elements: openness, assurance, sharing tasks, social networks, joint activities, mediated communication, avoidance, and humour.

The visualisation of the concept of maintaining relationships in the film "Bidadari Mencari Sayap" is applied using the large syntagmatic category from Christian Metz, which produces four syntagms and three autonomous shots to describe each shot and scene that describes the relational maintenance theory. 
Table 1. Mapping Relational Maintenances Theories in the Film "Bidadari Mencari Sayap"

\begin{tabular}{|c|c|c|c|c|c|c|c|c|c|c|c|}
\hline \multirow{2}{*}{ No. } & \multirow{2}{*}{ Scene Time Mark } & \multicolumn{10}{|c|}{ Relational Maintenances Theories } \\
\hline & & A & B & C & D & $E$ & $\mathrm{~F}$ & G & $\mathrm{H}$ & I & J \\
\hline 1 & $03.25-03.31$ & & & & & & & & V & & \\
\hline 2 & $04.43-04.53$ & & & & & & & & V & & \\
\hline 3 & $08.29-10.59$ & & & & & V & & & & & \\
\hline 4 & $12.39-13.34$ & V & & & & & V & & & & \\
\hline 5 & $13.47-14.33$ & & & & & & & & & & V \\
\hline 6 & $24.35-25.50$ & V & & & & & & & & & \\
\hline 7 & $26.51-29.29$ & & & & & V & & & & & \\
\hline 8 & 36.32 & & & & & & & & V & & \\
\hline 9 & 43.57 & & & & & & & & V & & \\
\hline 10 & $42.39-42.56$ & & & & & & & & V & & \\
\hline 11 & $48.43-48.50$ & & & & V & & & & & & \\
\hline 12 & $49.48-49.57$ & & & & V & & & & & & \\
\hline 13 & $57.05-57.36$ & & & & & & & & V & & \\
\hline 14 & $59.14-59.33$ & & & & & & & V & & & \\
\hline 15 & $01.03 .55-01.04 .06$ & & & V & & & & & & & \\
\hline 16 & $01.22 .53-01.25 .50$ & & & V & & & & & & & \\
\hline
\end{tabular}

Note: (A) Openness; (B) Positivity; (C) Assurance; (D) Sharing Task; (E) Social Network; (F) Join Activities; (G) Mediated Communication; (H) Avoidance; (I) Anti Social; (J) Humor

In Table 1, it can be seen that there are two scenes in the film "Bidadari Mencari Sayap", which depicts openness, assurance, sharing tasks, social networks, and one scene depicts joint activities, mediated communication and humour. In the movie "Bidadari Mencari Sayap," avoidance is the most common maintenance. There are six scenes in the film that indicate avoidance. 
Table 2. Mapping The Large Syntagmatic Category

\begin{tabular}{|r|l|l|l|l|l|l|l|l|l|l|}
\hline \multirow{2}{*}{ No. } & \multirow{2}{*}{ Scene Time Mark } & \multicolumn{7}{|c|}{ Semiotika Christian Metz } \\
\hline & & I & II & II & IV & V & VI & VII & VIII & IX \\
\hline 1 & $03.25-03.31$ & & & & & & & V & & \\
\hline 2 & $04.43-04.53$ & & & & & & & V & & \\
\hline 3 & $08.29-10.59$ & & & & & & & V & & \\
\hline 4 & $12.39-13.34$ & & & & & & & V & & \\
\hline 5 & $13.47-14.33$ & & & & & & & V & & \\
\hline 6 & $24.35-25.50$ & & & & & & & V & & \\
\hline 7 & $26.51-29.29$ & & & & & & & V & & \\
\hline 8 & 36.32 & V & & & & & & & & \\
\hline 9 & 43.57 & V & & & & & & & & \\
\hline 10 & $42.39-42.56$ & & V & & & & & & & \\
\hline 11 & $48.43-48.50$ & V & & & & & & & & \\
\hline 12 & $49.48-49.57$ & V & & & & & & & & \\
\hline 13 & $57.05-57.36$ & & & & & & & V & & \\
\hline 14 & $59.14-59.33$ & & & & & & V & & & \\
\hline 15 & $01.03 .55-01.04 .06$ & & & & & & & V & & \\
\hline 16 & $01.22 .53-01.25 .50$ & & & & & & & & V & \\
\hline
\end{tabular}

Note: (I) Autonomous Shot; (II) The Parallel Syntagm; (III) The Bracketing Syntagm; (IV) The Descriptive Syntagm; (V) The Descriptive Syntagm; (VI) The Alternating Syntagm; (VII) The Scene; (VIII) Episodic Sequence; (IX) Ordinary Sequence

Based on the large syntagmatic category from Christian Metz, four scenes use autonomous shots, and one scene uses parallel syntagm, alternating syntagm, and episodic sequences. In describing the concept of relational maintenance, it was found the use of nine scenes. The following section describes the data presented in Tables 1 and 2 specifically regarding Christian Metz's semiotics and relational maintenance theories from the film "Bidadari Mencari Sayap."

\section{Avoidance}

Avoidance is the attitude of a partner who avoids certain circumstances or particular issues to prevent conflict. This attitude is shown in several scenes in the film "Bidadari Mencari Sayap." 
Figure 1. Scene -03.21 and 03.25

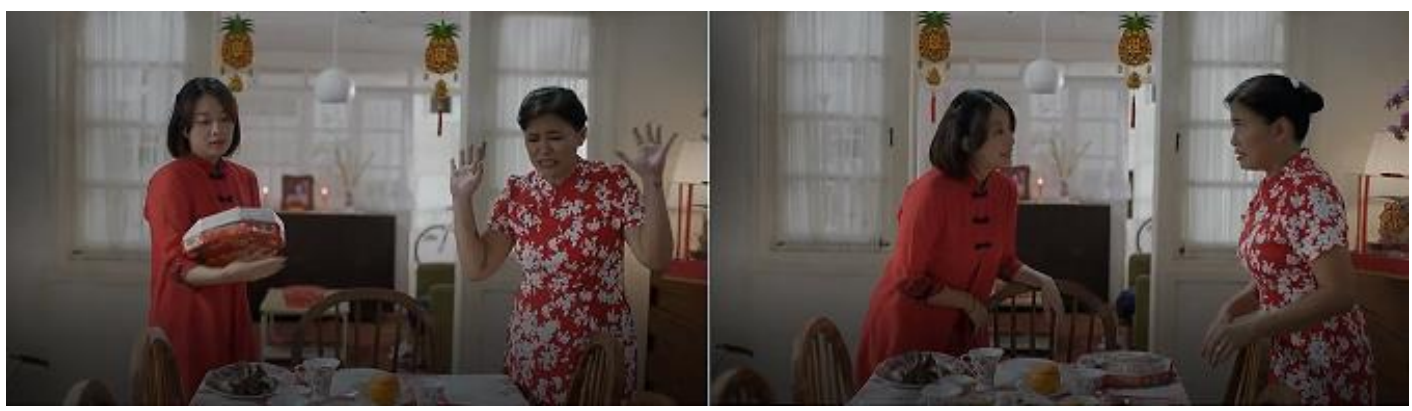

The time mark 03.25 - 03.31 describes the moment when Angela's sister complained about the condition of Angela's small and cramped house, which made the atmosphere at home feel cramped if visited by many people. As soon as her sister spoke like that, Angela immediately warned her sister to lower her voice so that her husband would not hear her. Angela felt that everyone in the house was very sensitive, both husband and Babah. Thus, Angela was afraid that her older sister's words would invite conflict if they were continued. The cut can be categorised as a scene because it consists of several shots that tell an event in sequence and appear without pause.

Avoidance in the film "Bidadari Mencari Sayap" is shown several times. At the time mark 04.43 - 04.53, after Babah asked for the food he ordered, Angela's sister brought Babah to pick it up. After that, Angela asked what food her Babah ordered. When she found out that the food ordered was pork, Angela immediately frowned and complained to her sister, saying, "if my husband finds out, it can be bad." From the conversation and the scene, it can be seen that Angela wants to avoid the situation currently happening, but she cannot avoid it because her sister brought Babah's meat without telling Angela first. The scene is a scene because it is still continuous with the previous scene in place, time and event.

The third avoidance sign is found in the same two shots but inserted at different times, namely at 36.32 and 43.57 minutes. Reza's actions as a husband are avoidance because he does not pick up Angela's phone, even though he knows that his wife is calling. Reza personally did this because of the secret he kept. Since Reza resigned from the office, he did not tell Angela anything and worked as an online driver to earn a side income. This part is an explanatory insert because it shows Angela calling in one short shot. The shot was inserted when Reza was working and carrying passengers in his car, making it impossible for Reza to pick up his wife's phone, who did not even know that he had changed jobs to become a driver. 
Figure 2. Parallel Syntagma 42.36 and 42.42

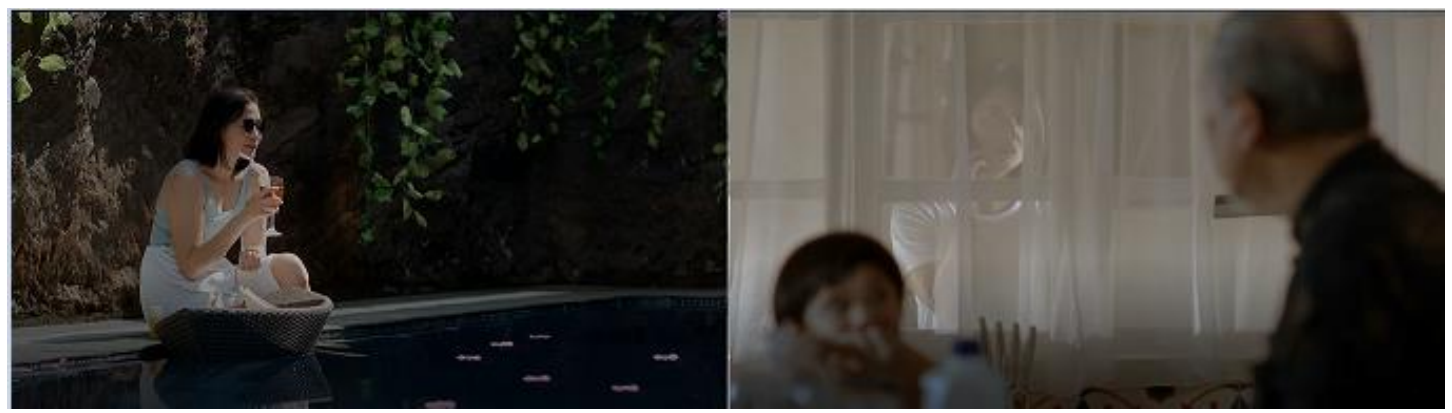

Figure 2 is a parallel syntagma which is also avoidance. The conversation that Angela and her older sister had had a stark contrast to their condition. In the scene, Angela's sister is sitting relaxing by the pool while enjoying juice. He offers Angela a job in her husband's office. Meanwhile, in another shot, Angela is seen picking up the phone outside the house. When she heard about the job offer from her sister, Angela still wanted to think first because she doubted that her husband would agree with the decision she was about to take at that time. Angela, who knew that her husband did not like it when he worked, did not immediately accept the job offer given by her sister.

Figure 3. Scene $57.05,57.13,57.28$, and 57.36

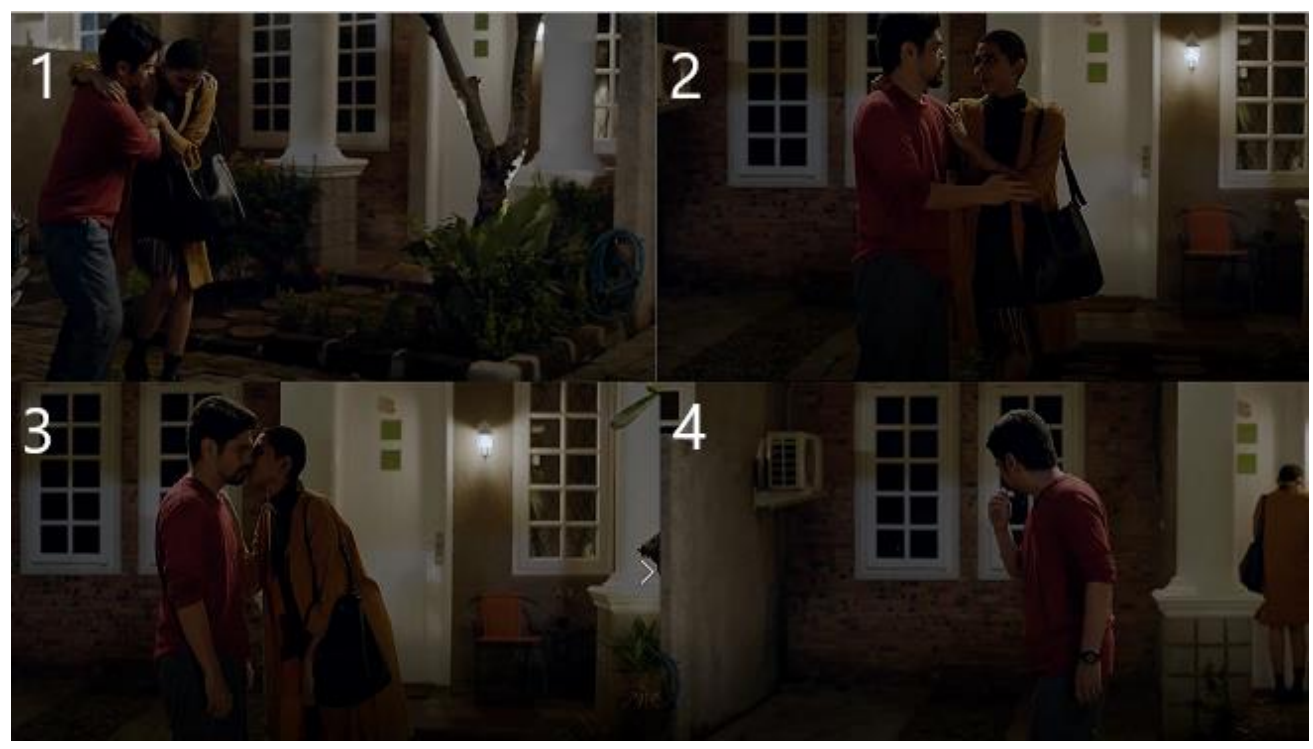

The last scene that depicts avoidance occurs at minutes $57.05-57.36$ when Reza delivers one of his boarding friends who has used his online driver service several times. The woman named Soraya was in a drunken state, expressed her feelings to Reza. Not only expressing her feelings, but Soraya also did not hesitate to invite Reza to stay in her room. Reza, who felt that this was wrong and should not be done, immediately refused Soraya's invitation to sleep together and chose to rest in their respective rooms. At minute 57.36, 
we can also see that Reza felt uncomfortable after Soraya suddenly kissed him on the cheek before entering his boarding room. The scene is a scene because it is a continuous series of shots and describes an event that is related and without pause.

\section{Social Networks}

When it comes to maintaining a relationship with a partner, the most important thing besides getting closer and understanding the partner is to approach the people around that partner. This is also depicted in the film "Bidadari Mencari Sayap." Both Reza and Angela were seen eating together with their respective families. Even though they looked uncomfortable, Reza and Angela continued to eat together with their families in the end.

Figure 4. Scene - 08.27, 08.33, 27.09 and 27.57

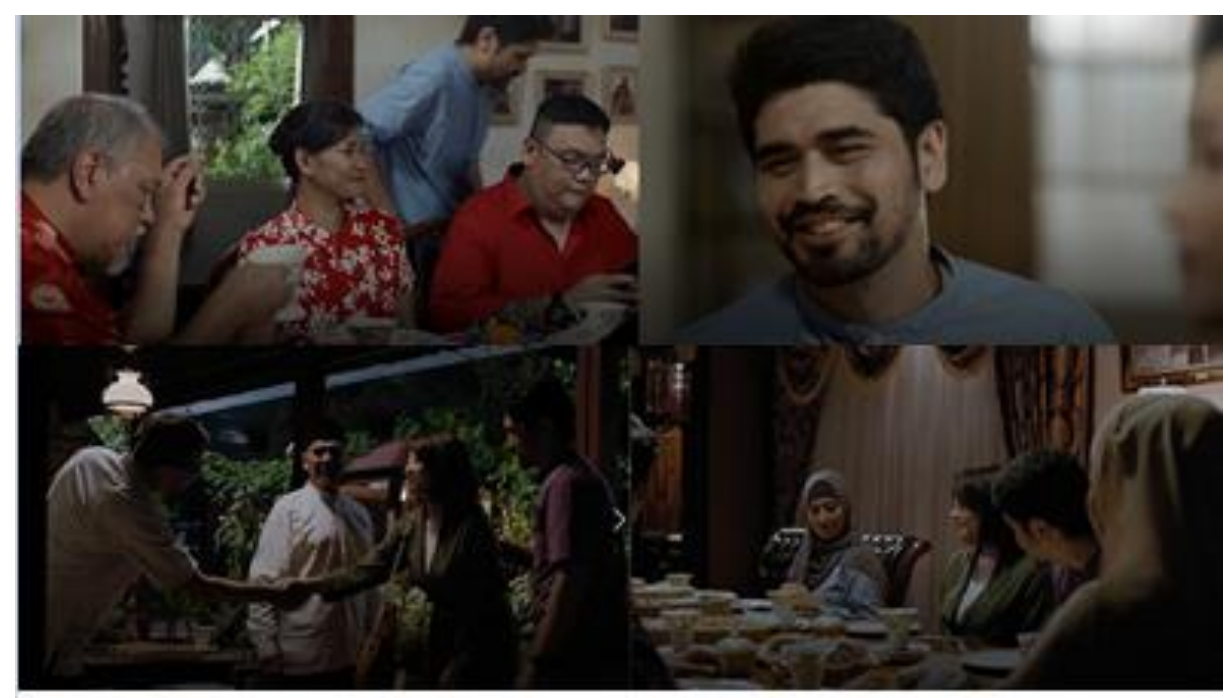

The scene at the beginning of the film shows Reza, who is eating with Angela's family during the Chinese New Year celebration. Unlike Angela's family, who wear red clothes typical of Chinese New Year celebrations, Reza wears blue clothes. Even though at first he refused to join the meal so that his wife could be closer to the family, Reza still attended the meal together and responded to various conversations addressed to him.

Not only Reza, but the film "Bidadari Mencari Sayap" also depicts Angela having dinner with Reza's family, who have Arab ancestry. Angela, who had previously refused to join the meal together, finally continued to eat together with her husband's family. When she came to Reza's family home, Angela brought food for Reza's parents. Unfortunately, Angela feels uncomfortable because Reza's mother often comments on her appearance, which is still not wearing the hijab, unlike Reza's father, who tends to understand. After all, change requires a process that is not instant. The depiction of the two family meals is shown in the form of a scene, which is a combination of several successive shots and seems to have no pause. 


\section{Openness}

In this scene, Angela and Reza are washing dishes while discussing an issue. Angela questioned the views and reasons why pork is considered haram in Islam. The discussion that initially sparked the debate was finally resolved amicably. At the time mark 12:39 to 13:34, Reza and Angela both expressed their feelings. Reza felt Angela began to pressure hims as Babah did. Hearing Reza's explanation, Angela apologised and explained to Reza that she actually just wanted to know more because she is a convert and still does not understand much of the teachings of Islam in detail. Hearing Angela's explanation, Reza also apologised to Angela.

The second scene occurred at minutes 24.35 to 25.50. Previously, Reza looked annoyed because of the dog in the yard and because his wife can not be contacted all day. The debate happened again when Angela also asked Reza the same thing. The debate was resolved because Angela finally tried to explain that she had to go to the doctor because of her allergies. Hearing Angela's explanation, Reza looked regretful and began to listen to his wife's story about the actual incident. Reza looks guilty and approaches his wife.

\section{Humour}

Figure 5. Scene - 13.55, 14.09 and 14.20

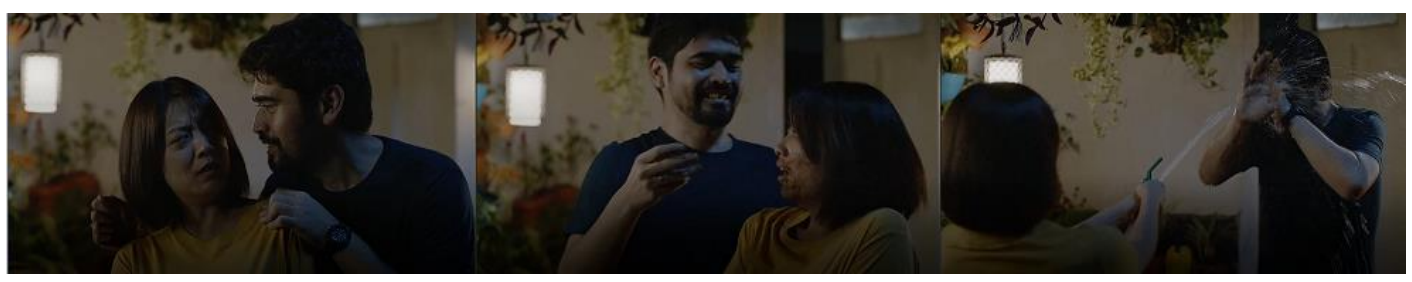

Figure 5 is a cut scene that takes place after the debate about pigs which is considered haram in Islam to have to wash everything that pigs touch with the soil. Angela felt that Reza was too emotional when explaining the issue, even though Angela was a convert who still did not understand the rules in Islam. Reza, who realised his mistake, finally tried to break the tense atmosphere by teasing Angela. Not consumed by Reza's seduction, Angela begins beating herself, who feels less than perfect as a wife. Anglea's statement made Reza cover Angela's mouth with his hands still covered with dirt. After that, Angela replied to Reza's actions by pouring water from the hose he was using.

\section{Sharing Task}

A partner must know the duties and roles in a relationship. During the fight, Reza left the house for a while and could not be contacted. However, Reza does not necessarily forget his duties as husband and head of the family. The time mark 48.43-48.50 portray when Babah wants to pay the rent from Angela and Reza's house, which he thought has not been paid. Shortly after that, the landlord immediately said that Reza had paid the rent 
via bank transfer. This action indicated that Reza was not negligent in carrying out his duties as a husband, even though he was not at home. He is still doing his job well.

Reza's second action, which shows sharing tasks, is when he transfers money to Angela at the time mark 49.48 to 49.57 . The shot includes a subjective insert because it was taken from the point of view of Angela, who was reading an incoming text message from Reza. The two shots that depict sharing tasks use autonomous shots, namely displaced diegetic and subjective insert.

\section{Mediated Communication}

As the name implies, mediated communication is communication that is carried out through certain media. In order to maintain a relationship with his wife, who was not doing well, plus he did not come home, and there was no news, Reza finally tried to contact Angela via cellphone chat.

Figure 6. Alternating Syntagma - 59.16 and 59.28

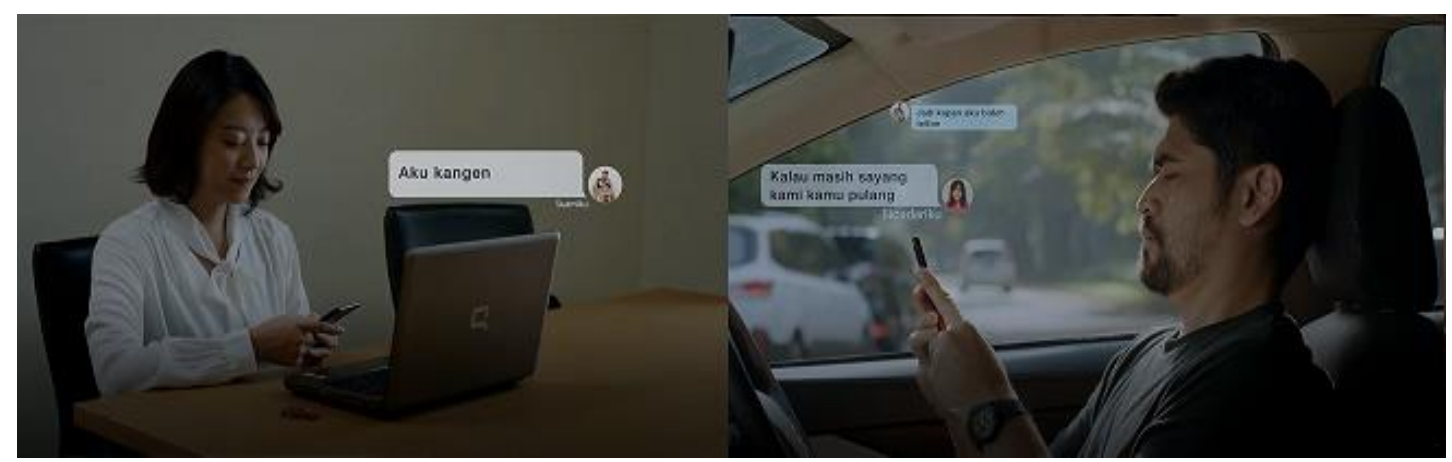

The conversation that took place between Reza and Angel during minutes 59.14 to 59.33 was included as an alternating syntagma because it featured two activities carried out at the same time, namely when Angela and Reza both replied to the chat at the same time but in different places.

\section{Joint Activities}

Joint activities are the actions of couples who do something together. In the movie "Bidadari Mencari Sayap," at the time mark 12.39 - 13.34, Reza and Angela clean the plates they have used for the Chinese New Year celebration at their home together. This is done to ease the burden of the partner.

\section{Assurance}

Assurance is the act of showing a clear commitment in a relationship. At minutes 01.03.53 to 01.04.11, there is a scene that shows assurance. In this scene, it is depicted that Reza returns home and is greeted by Angela with a warm gase and hug. After that, 
they together have sex which is certainly not shown in the film. This scene is given a fadeout effect, and the scene changes to the next day.

Figure 7. Episodic Sequence - 01.22.53, 01.23.18, 01.23.29, 01.23.33, 01.23.41, 01.23.54, $01.24 .07,01.24 .45,01.25 .01,01.25 .09,01.2510$, and 01.25 .18

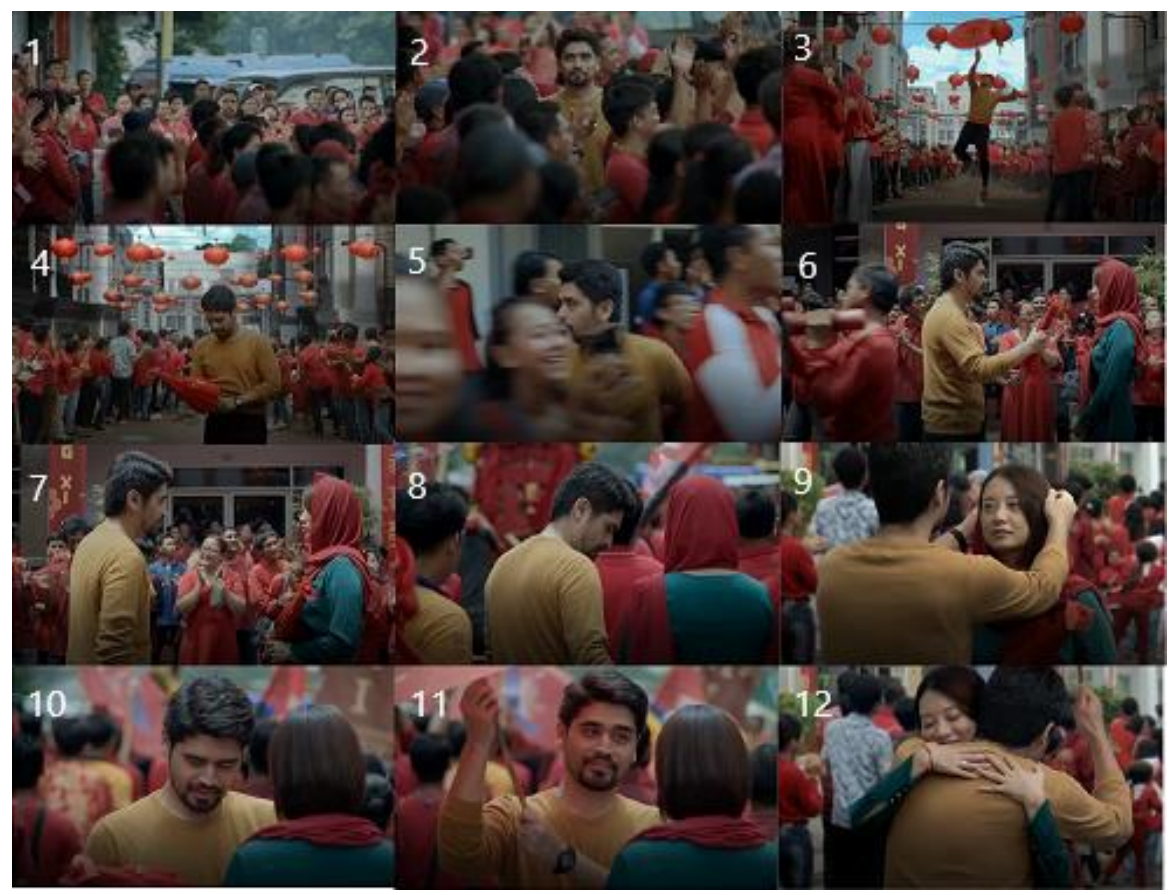

The closing part of the film "Bidadari Mencari Sayap" includes assurance when Reza, who left Angela, returns and wants to start again. The umbrella that Reza took was a substitute for the umbrella gift that Reza gave him, which was broken when they fought. The shots in this scene can be categorised as episodic sequences due to the complete depiction of events, starting from Reza appearing from the crowd and looking for Angela, taking the umbrella, closing the umbrella, running towards Angela until they hugged. 


\section{CONCLUSIONS}

Table 2. Relational Maintenances Theories \& Christian Metz Semiotics Summary

\begin{tabular}{|c|c|c|c|c|c|c|c|c|c|c|c|c|c|c|}
\hline \multirow{2}{*}{ No. } & \multirow{2}{*}{ Scene Time Mark } & \multicolumn{13}{|c|}{ Relational Maintenances Theories \& Christian Metz Semiotic } \\
\hline & & A & 1 & C & II & D & $\mathrm{VI}$ & $\mathrm{E}$ & VII & $\mathrm{F}$ & VIII & G & $\mathrm{H}$ & $\mathrm{J}$ \\
\hline 1 & $03.25-03.31$ & & & & & & & & V & & & & $\mathrm{V}$ & \\
\hline 2 & $04.43-04.53$ & & & & & & & & V & & & & $\mathrm{V}$ & \\
\hline 3 & $08.29-10.59$ & & & & & & & V & V & & & & & \\
\hline 4 & $12.39-13.34$ & V & & & & & & & V & V & & & & \\
\hline 5 & $13.47-14.33$ & & & & & & & & $\mathrm{~V}$ & & & & & V \\
\hline 6 & $24.35-25.50$ & V & & & & & & & $\mathrm{V}$ & & & & & \\
\hline 7 & $26.51-29.29$ & & & & & & & V & V & & & & & \\
\hline 8 & 36.32 & & V & & & & & & & & & & V & \\
\hline 9 & 43.57 & & V & & & & & & & & & & V & \\
\hline 10 & $42.39-42.56$ & & & & V & & & & & & & & V & \\
\hline 11 & $48.43-48.50$ & & $\mathrm{~V}$ & & & $\mathrm{~V}$ & & & & & & & & \\
\hline 12 & $49.48-49.57$ & & V & & & V & & & & & & & & \\
\hline 13 & $57.05-57.36$ & & & & & & & & V & & & & V & \\
\hline 14 & $59.14-59.33$ & & & & & & V & & & & & V & & \\
\hline 15 & $01.03 .55-01.04 .06$ & & & $\mathrm{~V}$ & & & & & $\mathrm{~V}$ & & & & & \\
\hline 16 & $01.22 .53-01.25 .50$ & & & $\mathrm{~V}$ & & & & & & & V & & & \\
\hline
\end{tabular}

Note: (A) Openness; (I) Autonomous Shot; (C) Assurance; (II) The Parallel Syntagm ;(D) Sharing Task; (VI) The Alternating Syntagm; (E) Social Network; (VII) The Scene; (F) Join Activities; (VIII) Episodic Sequence; (G) Mediated Communication; (H) Avoidance; (J) Humor

Based on the analysis results, in the film "Bidadari Mencari Sayap," it was found that relational maintenance theories were displayed using four syntagms and three autonomous shots. The act of maintaining a relationship that is most often shown in the film "Bidadari Mencari Sayap" is avoidance, which is five times. Avoidance is shown in some parts by using scenes, autonomous shot explanatory inserts, and parallel syntagma. Social networks and also openness in maintaining a relationship are shown twice, each using the scene.

In the movie "Bidadari Mencari Sayap," the action is shown once using a scene. In addition, the sharing task is displayed twice using an autonomous shot, and the difference is the type of autonomous shot used. The first shot is a displaced dietetic and the second is a subjective insert. In the film "Bidadari Mencari Sayap", an alternating syntagma is also shown when the two characters are communicating using the chat feature via a smartphone. Joint activities are carried out once using a scene. Finally, assurance is shown twice. The first scene is shown using a scene, and the second scene using an episodic sequence.

Of the ten elements of relational maintenance theories, the film "Bidadari Mencari Sayap" uses eight elements. Avoidance is a way of maintaining relationships that are most often shown in films, where each partner prevents conflict from occurring by avoiding the cause of the conflict. In addition, other values shown are openness. Indeed, 
in building a relationship, openness to one another must be done. In the film, Angela and Reza each have personal problems, which eventually become the cause of conflict due to their openness from the start about their problems.

In family life, Reza and Angela have their respective duties as husband and wife. They share tasks together. Fostering relationships in married life is basically done not only on the partners but also on the partner's family. In reality, diversity and differences are not actually a barrier but can be a strength if faced in the right way.

Finally, the author hopes that the audience can understand and interpret the values in the film "Bidadari Mencari Sayap" in more depth. In addition, the author also hopes that the audience can absorb the positive messages implied in the film so that they can be implemented in real life. 


\section{REFERENCE}

Abadi, R., Jers, L. O. T., \& Hasniah. (2017). Adaptasi Dalam Berumah Tangga Setelah Pindah Agama. Jurnal Kabanti, 1(2), 10-18. http://journal.fib.uho.ac.id/index.php/kabantiantropologi/article/view/255

Abdilah, \& Sjafe'i, M. S. (2019). Konversi Agama (Studi Fenomenologi Pada Mualaf Tionghoa di Kota Banda Aceh). Jurnal IImiah Mahasiswa FISIP Unsyiah, 4(4). http://www.jim.unsyiah.ac.id/FISIP/article/view/12933/5609

Ali, M. M. (2019). Analisis Gender Film Salah Bodi Melalui Semiotika Christian Metz. Gelar : Jurnal Seni Budaya, 16(1), 59-76. https://doi.org/10.33153/glr.v16i1.2340

B, L., Monto, L. O., \& Arsyad, M. (2018). Konflik Perkawinan dan Cara Penyelesaian Melalui Tokoh Adat (Studi di Desa Labone Kecamatan Lasalepa Kabupaten Muna). $\begin{array}{llll}\text { Jurnal Neo Socielal, 3(2), 362-373. } & \text { 36 }\end{array}$ https://doi.org/http://dx.doi.org/10.52423/jns.v3i2.4023

BPS. (2021). Catalog : Statistik Indonesia 2021 (pp. xliv-758). Badan Pusat Statistik.

Canary, D. J., \& Yum, Y. (2015). Relationship Maintenance Strategies. In The International Encyclopedia of Interpersonal Communication (Vol. 1, Issue 1, pp. 1-9). https://doi.org/10.1002/9781118540190.wbeic248

Diananto, W. (2020, September). Garin Nugroho Beri Hadiah Tak Biasa untuk Sineas Aria Kusumadewa, Apa Bentuknya? Liputan6.Com. https://www.liputan6.com/showbiz/read/4369743/garin-nugroho-beri-hadiah-takbiasa-untuk-sineas-aria-kusumadewa-apa-bentuknya

Erviannisa, F., \& Christantyawati, N. (2019). Representasi banjir dalam film "Love at First Flood" di Thailand. Jurnal Kajian Media, 3(2), 132-156. https://doi.org/10.25139/jkm.v3i2.2007

Farady Marta, R., \& Robin, P. (2019). Kebahasaan Sinematik Bernuansa Pluralitas dalam Iklan BNI Taplus Anak. Communication, 10(1), 16. https://doi.org/10.36080/comm.v10i1.810

Fernando, J., Marta, R. F., \& Hidayati, R. K. (2020). Reaktualisasi mahasiswa diaspora Indonesia dalam menjaga identitas budaya bangsa di Benua Australia. Jurnal Kajian Komunikasi, 8(2), 194. https://doi.org/10.24198/jkk.v8i2.25219

Ghony, D., \& Almanshur, F. (2010). Metodologi Penelitian Kualitatif. In Metodologi Penelitian Kualitatif. In E. D. Lestari (Ed.). Sukabumi: CV Jejak

Indriani, S. S., \& Rosfiantika, E. (2018). Pesan Rasisme dalam Episode the Vinyards pada Film American History X. ProTVF, 2(1), 87. https://doi.org/10.24198/ptvf.v2i1.19879

Isnaini, H., \& Arzak, M. (2019). Pasaji Ponan sebagai Wujud Komunikasi Budaya (Studi Interpretatif terhadap Masyarakat Desa Poto Kecamatan Moyo Hilir dalam Memaknai Tradisi Pasaji Ponan). Kaganga Journal of Communcaition Science, 1(1), 1-16. http://www.jurnal.uts.ac.id/index.php/KAGANGA/article/view/408

Lilis, A., Dewi, K., Zamroni, M., Astuti, S. Y., Budaya, F. I., \& Jember, U. (2017). Analisis Semiotika Film Christian Metz: Studi Kasus Visualisasi Pesan. Publika Budaya, 5(1), 21-27. https://jurnal.unej.ac.id/index.php/PB/article/view/5986

Mujahidah, N. H., \& Jaunedi, F. (2021). Penerimaan Penonton Mengenai Peran Gender Pada Karakter Perempuan Dalam Film Bumi Manusia. Bricolage : Jurnal Magister IImu Komunikasi, 7(1), 95-104. 
Nurhasanah, L. A., \& Naryono, A. (2017). Interpersonal Communication Strategy for Maintaining Post-Violance Relationship. Interaksi Online, 5(3), 1-11. https://ejournal3.undip.ac.id/index.php/interaksi-online/article/view/16748

Oktavianus, P. J. (2018). Analisis Semiotika Ketidakadilan Gender Terhadap Perempuan Dalam Film Marlina Si Pembunuh Empat Babal. JISIP : Jurnal IImu Sosial Dan IImu Politik, 7(2), 136-147. https://doi.org/https://doi.org/10.33366/jisip.v7i3.1591

Prameswari, T. M. (2017). Pengambilan Keputusan Sebagai Penyelesaian Konflik Dalam Hubungan Berpacaran. Interaksi Onlinei, 5(2), 1-5. https://ejournal3.undip.ac.id/index.php/interaksi-online/article/view/16070

Sari, R. P. (2020). Bidadari Mencari Sayap, Saat Perbedaan Keyakinan Menggoyang Rumah Tangga Rizky Hanggono dan Leony. Kompas.Com. https://www.kompas.com/hype/read/2020/09/30/161024366/bidadari-mencarisayap-saat-perbedaan-keyakinan-menggoyang-rumah-tangga?page=all

Sidabutar, E. T. (2019). Makna Kerja Keras dalam Film "La La Land", Jurnal Riset Komunikasi, 2(2), 171-183. https://doi.org/10.24329/jurkom.v2i2.68

Sitompul, E. A., \& Simaremar, J. A. (2017). Analisis Fungsi, Nilai Budaya dan Kearifan Lokal dalam Film Sinamot Karya Sineas Muda Medan: Kajian Antropolinguistik. Suluh Pendidikan, 4(2), 24-37. http://jsp.uhn.ac.id/wp-content/uploads/2018/03/04Jurnal-Eden-Sitompul.pdf

Suryanto. (2016). Analisis Perbandingan Interpretasi Penokohan antara Novel dan Film 99 Cahaya di Langit Erora. Jurnal Proporsi, 1(2), 153-164. https://doi.org/http://dx.doi.org/10.22303/proporsi.1.2.2016.153-164

Tianotak, J., \& Asy'ari, N. A. S. (2019). Makna Tagline 'Menjadi yang Terbaik' Iklan Telkomsel Versi Pilot Papua Riko Kabak, Bricolage : Jurnal Magister IImu Komunikasi, 5(1), 49-72. https://doi.org/10.30813/bricolage.v5i01.1742

Zuhri, A. M., \& Wahyudi, W. E. (2019). Teologi Sosial Muslim Tionghoa: Empirisma, 29(2), 103-112. https://www.jurnal.iainkediri.ac.id/index.php/empirisma/article/viewFile/ $2345 / 1087$ 